\title{
A Comparative Study on Socio-Economic Status and Expenditure Pattern of Tribal Farmers
}

\author{
Homang Chetri ${ }^{1}$, Raju Sharma², Durga Devi ${ }^{3}$, Jayashree Bordoloi ${ }^{4}$, Bikram Pegu ${ }^{5}$, Debashree Kashyap ${ }^{6}$ \\ ${ }^{\text {I} A s s i s t a n t ~ P r o f e s s o r, ~ D e p a r t m e n t ~ o f ~ E c o n o m i c s, ~ M i s s a m a r i ~ C o l l e g e, ~ A s s a m, ~ I n d i a . ~}$ \\ ${ }^{2}$ Research Scholar, Department of Economics, Gauhati University, Assam, India. \\ ${ }^{3}$ Research Scholar, Department of Economics, Gauhati University, Assam, India. \\ ${ }^{4}$ Research Scholar, Department of Business Administration, Tezpur University, Assam, India. \\ ${ }^{5}$ Research Scholar, Department of Economics, Gauhati University, Assam, India. \\ ${ }^{6}$ Research Scholar, Department of Economics, Gauhati University, Assam, India. \\ ORCID: 0000-0001-9739-4840 (Homang Chettri)
}

\begin{abstract}
:
Agriculture is the main source of livelihood in Assam and it contributed over 19 per cent to state domestic product (SDP) in 2010-11. But the farmers are still suppressed class even after seven decades of Independence. This may be for various reasons. In Assam Majority farmers are from tribal population where their living standard is very low. So, the present study reveals the Socio-economic Status and expenditure pattern of Tribal Farmers of sonitpur district of Assam. The study area has been chosen Thelamara circle of the district. The data has been collected on the basis of personal interview by survey method to each of the farmer through a predetermined questionnaire. A total sample of 80 farmers has been collected purposively from four different villages of the circle. The study revealed that Tribal farmers are very poor farmers with low literacy and knowledge about agricultural methods in comparison to non Tribal farmers.
\end{abstract}

Keywords: Tribal farmer, Non Tribal farmer, Agriculture, Sonitpur, socio-economic, Expenditure pattern, Consumption

\section{INTRODUCTION}

Agriculture is the main source of livelihood in Assam and the agriculture sector contributed over 19 per cent of the state income to state domestic product (SDP) in 2010-11. But the farmers are still suppressed class even after seven decades of Independence. This may be for various reasons. In Assam Majority farmers are from tribal population where their living standard is very low in comparison to non tribal farmers. A tribe is a social group usually with a definite area, dialect, cultural homogeneity and unifying social organization (Winick, 1956). India has $8.6 \%$ tribal population which is more than 104 million (Census, 2011).

In Assam more than 70 percent of the state's population depends on agriculture as farmers, as agricultural labours or both for their livelihood. We all know that more than $85 \%$ people of Assam live in villages where majority of them largely depends on farming. In Assam, the agriculture sector has not been developed significantly. This has greatly affected the Tribal farmers of the state compare to other farmers since a significant number of tribal populations lived in Assam.

The tribals owing to their life style and community habits and habitats have not been able to keep pace with the modern society. Tribals are not as advanced as the people of rest of India (Sikha Deka and et al, 2017). Thus majority of the Tribal population had to struggle to earn their livelihood. Poverty compelled people to be thrifty. Wages earned by the people were very low and therefore, income earned from these works was very less. Thus under this critical condition people were unable to have quality food and some were not able to get two meals a day.

Further, the subsistence life of the Tribal people hinders the standard of living and socio-economic activities. Because of subsistence level of life, the people of this region were deprived of status in the society too.

\section{REVIEW OF LITERATURE}

Chakravarty and patnaik (1989) found that absolute income level of household or its income trends is more significant in determining its consumption and investment expenditure in consumer durable goods, luxury goods and valuable assets.

A study team undertaken by the Planning Commission in 1969 revealed that the Tribal Welfare Policy should aim at the progressive development of the social and economic life of the tribals with a view to their gradual integration which a rest of the community on a footing of equality within reasonable distance of time.

Sharma (1978) revealed that the hilly areas and tribal areas constituted special problem areas as they were backward and 
inaccessible and also were neglected and exploited for centuries.

Parag Das (2015) studied that the main problems of the rural farmers are the chronic poverty, illiteracy, lack of mechanisation, scarcity of HYV inputs, lack of capital formation, flood and drought, poor agricultural marketing facilities and lack of knowledge about demandable crops or the absence of commercialization of agriculture sector.

Sikha Deka and et al (2017) found that Tribal people are very poor farmers with low literacy and knowledge about agricultural methods and they grow only rice, tea and oranges without any awareness.

\section{CONCEPTUAL FRAMEWORK}

\section{Brief description of variables}

Food expenditure: Food expenditure is considered to be basic for the daily life of the farmers. Since it is fixed expenditure, it does not impact on increasing total expenditure.

- Size of vehicle: Possession of vehicle significantly influences the total expenditure of the tribal farmers.

- Clothing and wearing expenditure: The frequency of buying clothings and wearing impacts the total expenditure of the tribal farmers

- Total Income: It is quite obvious that expenditure of the family depends on the total income of the family members.

- Size of family: Total expenditure of farmers also relies on size of family members.

- Size of school going children: The number of school going children affects the total expenditure of the family. The greater the number of number of school going children larger will be the amount of expenditure

\section{RESEARCH GAP}

Various research paper, journals and dissertations have been reviewed and it is found that very little research has been carried out on the socio-economic status of Tribal farmers. The lower living standard of the tribal farmer in comparison other farmer also evokes the concern for the present study.

\section{RATIONALE TO THE STUDY}

Tribal population takes a great position in the population structure of Assam. Tribal population attracted the government policies of either central or state government since a long time. But, the government policies to the tribal population are not so effective since tribal farmers believed to be living lower standard life in the region. The causes of lower standard of the people are multiple but very little study has been done in the problems of tribal farmers. It is believed that after the research of tribal farmers it will rationalize the policies of policy makers in an effective way.

\section{OBJECTIVES}

The present study based on the following objectives.

1. To compare the socio-economic characteristics of Tribal and Non Tribal farmers.

2. To investigate the important factors affecting Expenditure pattern of Tribal farmers.

3. To investigate the causes of low standard of tribal farmers.

\section{METHODOLOGY}

\section{A. Data Source}

Present study is based on both primary and secondary data. Primary data is collected based on survey sampling method purposively investigated from sonitpur district of Assam. The secondary data is collected from district census data, Statistical Handbook of Assam, Census 2011.

\section{B. Line of Analysis}

$>$ To fulfill the first objective, Percentage, Tabulation, Graphs has been used.

$>$ To fulfill the second objective, OLSE Model run by SPSS software has been used.

$>$ To fulfill the third objective, Qualitative description method has been used.

\section{Sampling Design}

Three stages of sampling design has been followed for the present study.

Stage1: The thelamara circle of Sonitpur district has been chosen for the study.

$>$ Stage 2: Four Villages namely; Dhekipelowa Kachari Gaon, Kalamatigate, Borjuli and Patidoi bherela has been selected for the present study.

$>$ Stage 3: Total 80 samples has been collected from the study area where 40 of them from Tribal farmers and 40 samples from Non Tribal farmers.

\section{PROFILE OF THE STUDY AREA: SONITPUR DISTRICT}

The Sonitpur district is situated between Brahmaputra River and Himalayan Fothil of Arunachal Pradesh. The district is in the site of Northern corner of Assam, bounded to the north by the Arunachal Pradesh, to the east by Biswanath district, to the south by the Brahmaputra River, and to the west by Darrang District. It is spread over an area of $5324 \mathrm{~km}^{2}$ on the northern bank of Brahmaputra, the life line of Assam. The total geographical area of the district is 271729 hectares which is only $6.8 \%$ of Assam. Whereas according to Census 2011, 
Sonitpur had population of $1,924,110$ which is $6.17 \%$ of total population of Assam.

The population growth of the district over the decade 20012011 was $15.55 \%$ which is less than $18.11 \%$ of the previous decade 1991-2001. According to census of 2011, the literacy rate of the district is $67.34 \%$ which is more than the previous literacy of $59.03 \%$ in 2001.

Table 1: Distribution of Workers

\begin{tabular}{|l|l|l|}
\hline & Nos. of Farm Families & In Percentage \\
\hline Large farmers & 12,728 & $12 \%$ \\
\hline Small farmers & 39,245 & $37 \%$ \\
\hline Marginal farmers & 38,184 & $36 \%$ \\
\hline Landless farmers & 15,910 & $15 \%$ \\
\hline SC farmers & 9,281 & $8.75 \%$ \\
\hline ST farmers & 14,118 & $13.3 \%$ \\
\hline Total & $1,06,067$ & \\
\hline
\end{tabular}

Source: Census, 2011

The total number of farm families are 1,06,067 out of which $12 \%$ is Large farmers, $37 \%$ small farmers, $36 \%$ marginal farmers, $15 \%$ landless farmers, $8.75 \%$ SC farmers and $13.3 \%$ ST farmers. It is seen that Majority of the farmers are small and marginal farmer.

\section{RESULTS AND DISCUSSION}

\section{A. A comparison of Socio-economic status of Tribal} farmers and non tribal farmers

Since this study is a comparative study, it is very essential to know the conditions of the farmer based on whether they are tribal or not. Here information is collected regarding the socio-economic conditions and educational attributes of the people from the study region. Socio-economic status comparison of Tribal farmers and non tribal farmers has been categorized into five indicators i.e, Literacy, Types of house, Land holding pattern, Credit borrowing and means of agriculture. Since these indicators greatly influence the living standard of the farmers.

\section{Literacy of the Farmers}

Literacy play pivotal role in determining an individual's status and activities. It cannot be denied the fact that there is corelation between the caste, economic status and level of education. Moreover, Education is an essential factor of dignity and to social change and progress.

Table 2: Education farmers

\begin{tabular}{|l|l|l|l|l|}
\hline \multirow{2}{*}{ Literacy } & \multicolumn{2}{|l|}{ Tribal Farmers } & \multicolumn{2}{l|}{ Non Tribal Farmers } \\
\cline { 2 - 5 } & Frequency & In percentage & Frequency & In percentage \\
\hline Up to 10 standard & 20 & $50 \%$ & 12 & $30 \%$ \\
\hline Up to 12 Standard & 8 & $20 \%$ & 25 & $62.50 \%$ \\
\hline $\begin{array}{l}\text { Graduates/Post } \\
\text { Graduates }\end{array}$ & 3 & $7.50 \%$ & 2 & $5 \%$ \\
\hline Non literate & 9 & $22.50 \%$ & 1 & $2.50 \%$ \\
\hline
\end{tabular}

Source: Field survey

The table 1 shows that majority of Tribal farmers i.e. $72.50 \%$ have the qualification less than 10 standards in comparison to Non tribal farmers. On the other hand, $62.50 \%$ of Non Tribal farmers have qualification of 12 standards where it is only $20 \%$ in case of Tribal farmers. This indicates that Tribal farmers have lower literacy rates in comparison to Non Tribal farmers.

\subsubsection{Types of House}

Type of house is considered as the indicator of standard of living of farmers. In the study area, everyone has their own houses. But, the types of house in which they live is presented in the following table. 
Table 3: Types of house possess by farmers

\begin{tabular}{|l|l|l|l|l|}
\hline \multirow{2}{*}{ Types of house } & \multicolumn{2}{|l|}{ Tribal Farmers } & \multicolumn{2}{l|}{ Non Tribal Farmers } \\
\cline { 2 - 5 } & Frequency & In percentage & Frequency & In percentage \\
\hline Kachha House & 26 & $65 \%$ & 5 & $12.50 \%$ \\
\hline $\begin{array}{l}\text { Semi Pucca } \\
\text { Houses }\end{array}$ & 6 & $15 \%$ & 15 & $37.50 \%$ \\
\hline Pucca Houses & 3 & & & $42.50 \%$ \\
\hline PMAY & 5 & $7.50 \%$ & 17 & $7.50 \%$ \\
\hline
\end{tabular}

Source: Field Survey

It is found that $65 \%$ of Tribal farmers live in Kachcha house where as only $12.50 \%$ of Non Tribal farmers live in kachcha house. The living standard of Tribal farmers is seen as low in comparison to non Tribal farmers in the study area.

\section{Land Holding Pattern}

The farmers are classified on the basis of land holding pattern. The land holding pattern of study area has been analysed in the following table. It is revealed the study that majority of Tribal farmers are marginal and small farmers where they owned less than 2 hectares of land. On the other hand, majority of Non Tribal farmers are large farmers where they possess more than 2 hectares of land.

Table 4: Land holding pattern by the farmers

\begin{tabular}{|c|c|c|c|c|c|}
\hline \multirow{2}{*}{$\begin{array}{l}\text { Types of } \\
\text { Farmer }\end{array}$} & \multirow{2}{*}{$\begin{array}{l}\text { Size of Land } \\
\text { holding }\end{array}$} & \multicolumn{2}{|c|}{ Tribal Farmers } & \multicolumn{2}{|c|}{ Non Tribal Farmers } \\
\hline & & Nos & In \% & Nos & In \% \\
\hline Marginal & $<1$ hectares & 10 & $25 \%$ & 4 & $10 \%$ \\
\hline Small & 1 to 2 hectares & 25 & $62.50 \%$ & 22 & $55 \%$ \\
\hline Large & $>2$ hectares & 5 & $12.50 \%$ & 24 & $60 \%$ \\
\hline
\end{tabular}

Source: Field study

\section{Credit Borrowing}

Credit borrowing is the main factors that affect the agriculture productivity of farmers. It is seen that majority of the Tribal famers borrow money from money lender
(37.50\%) whereas Non Tribal farmers borrow money from banks $(55 \%)$.

Table 5: Credit Borrowing by the farmers

\begin{tabular}{|l|l|l|l|l|}
\hline \multirow{2}{*}{$\begin{array}{l}\text { Types of } \\
\text { borrowing }\end{array}$} & \multicolumn{2}{|l|}{ Tribal Farmers } & \multicolumn{2}{l|}{ Non Tribal Farmers } \\
\cline { 2 - 5 } & Frequency & In percentage & Frequency & In percentage \\
\hline Banks & 10 & $25 \%$ & 22 & $55 \%$ \\
\hline Money lender & 15 & $37.50 \%$ & 5 & $12.50 \%$ \\
\hline SHG & 10 & $25 \%$ & 8 & $20 \%$ \\
\hline Non borrower & 5 & $12.50 \%$ & 5 & $12.50 \%$ \\
\hline
\end{tabular}

Source: Field Study

\section{Means of Agriculture}

It is found from the present study that $65 \%$ of Tribal farmers use traditional method of cultivation whereas only $10 \%$ Non Tribal farmers use traditional method of cultivation. 
Table 6: Model Summary

\begin{tabular}{|l|l|l|l|l|}
\hline Model & R & R Square & Adjusted R Square & Std. Error of the estimate \\
\hline 1 & .923 & .973 & .713 & 4.92 \\
\hline
\end{tabular}

Source: SPSS Calculation

Table 7: Co-efficient

\begin{tabular}{|l|l|l|l|l|l|}
\hline \multirow{2}{*}{ Model } & \multicolumn{2}{|l|}{ Unstandardized Coefficients } & Standardized Coefficients & \multirow{2}{*}{ Sig. } & \\
\cline { 2 - 6 } & B & Std. Error & Beta & & \\
\hline (constant) & 79.308 & 16.885 & & 4.721 & .624 \\
\hline FD & .768 & .310 & .588 & 2.481 & .025 \\
\hline Vh & 1.082 & .261 & -.898 & -4.137 & .001 \\
\hline CW & 1.789 & .352 & .748 & 5.086 & .511 \\
\hline FS & 36.961 & 25.692 & -.270 & -1.439 & .000 \\
\hline SC & .004 & .016 & -.037 & -.260 & .003 \\
\hline \multicolumn{2}{|l|}{ a. Dependent Variable: TE } & & & \\
\hline
\end{tabular}

Source: SPSS Calculation

\section{B. Expenditure pattern of Tribal farmers}

In order to investigate the important factors affecting the expenditure pattern of Tribal farmers, the study uses one regression model by taking Total Expendture as dependent variable. The regression model is estimated using Ordinary Least Square Method. The model used for the present study is given below:

$\mathrm{TE}_{\mathrm{i}}=\beta_{0}+\beta_{1}\left(\mathrm{FD}_{\mathrm{i}}\right)+\beta_{2}\left(\mathrm{VH}_{\mathrm{i}}\right)+\beta_{3}\left(\mathrm{CW}_{\mathrm{i}}\right)+\beta_{4}\left(\mathrm{FS}_{\mathrm{i}}\right)+\beta_{5}\left(\mathrm{SC}_{\mathrm{i}}\right)+\mathrm{U}_{\mathrm{i}}$

Where,

\section{Dependent Variable:}

$\mathrm{TE}=$ Total Expenditure per year of the $\mathrm{i}^{\text {th }}$ tribal farmers.

\section{Independent Variable:}

$\mathrm{FD}_{\mathrm{i}}=$ Expenditure on food

$\mathrm{VH}_{\mathrm{i}}=$ Vehicle owned

$\mathrm{CW}_{\mathrm{i}}=$ Expenditure on Clothing and wearing,

Medical

$\mathrm{FS}_{\mathrm{i}}=$ Size of family members

$\mathrm{SC}_{\mathrm{i}}=$ Size of school going children

$\mathrm{U}_{\mathrm{i}}=$ Error term

\section{Analysis of the results}

The model summary is presented in the following table.

From the table it is found that the $\mathrm{R}^{2}$ value of the model is
0.973 which indicates that the independent variables explain 97.3\% variations in the dependent variables. It means the model give a very good fit.

It is found that coefficient of the explanatory variables such as vehicle owned and size of the family are 1.082 and 36.961 respectively which are significant at $1 \%$ level of significance. The estimated coefficient size of the school going children is .004 which is also significant at $5 \%$ level of significance. The other explanatory variables expenditure on food and expenditure on clothing and medical not significant which implies these factors do not impact on total expenditure of the tribal farmers significantly.

\section{Causes of low standard of Tribal farmers}

Lack of employment: Majority of tribal farmers depends on agriculture depends on agriculture. Since tribal people possess no skill or training, so there is no alternative employment opportunities as well. 96\% tribal farmers in the study area believed that there is no employment opportunity and they have to indulge on agriculture for this reason.

Seasonal nature of agriculture: Since most of the tribal farmers opted tradition way of farming, so they have to depend on monsoon for their crop sowing. Further, in the study region, majority people have to remain idle throughout the year since in agriculture farmers have to work only 2-3 months of a year. More than $60 \%$ tribal farmers have no works except from agriculture, so they have to struggle for which they have low level of living standard.

Poverty: Poverty of the farmers causes further low standard of living since they are not in a position to adopt expensive and modern technology of farming. It is observed from study that $35 \%$ of tribal farmers are resource poor in the study region where they do not have own means of agriculture.

Indebtness of the farmers: Majority of the tribal farmers 
used to borrow money from money lender and other noninstitutional sources and the interest rate is very high on this. So, they are prone to indebtness or vicious circle of poverty since a lion's share of their income has to be used as the repayment of loan. $37.50 \%$ of tribal farmers used to borrow money from money lenders for their agricultural activities. This causes the lower standard of living among tribal farmers.

\section{CONCLUSION}

In the present study, it was observed that the tribal farmers are socio-economically backward as compared to the non-tribal farmers in the study area.. So as to eradicate the problems of tribal farmers, it is necessary for the policy makers to identify and quantify the socio-economic factors which are inhibiting their growth and development. The tribal farmers due to their lower living standard have not been able to keep pace with the modern society. Tribal farmers are not as advanced as the other farmers of Assam.

\section{REFERENCES}

[1] Bagchi, S. AAxomor sah silpa.@ in Phukan (1997), pp. 64-85.

[2] Bhuyan, S. A State intervention in agricultural marketing: Is it necessary? @ Agricultural Marketing, 33, 1 (April 1990):2-13.

[3] Dhar, P. K. Axomor arthanitir ruprekha (The Economy of Assam). Kalyani Publishers: Ludhiana, 1994.

[4] Knutson, R. D., J.B. Penn, and Barry L. Flinchbaugh. Agricultural and Food Policy. 4th ed., Prentice Hall: Upper Saddle River, NJ, 1998.

[5] Phukan, A. K. Z (ed.). Axomor arthaniti, 1997 (The Economy of Assam, 1997). Buniyad: Guwahati, 1997.

[6] Bhagabati A.K, Bora A.K, and Kar B.K. Geography of Assam, Rajesh Publication, New Delhi

[7] Rural Farmers' Problems Accessing Agricultural Information: A Case Study of Nsukka Local Government Area of Enugu State, Nigeria, Nnenna A. Obidike (Nnamdi Azikiwe Library) University of Nigeria, Nsukka

[8] Dr Tyagi B. P. Agricultural Economics and Rural Develoment, Jai Prakash Nath \& Co. Meerut, fifth edition 1996.

[9] Parag Das, (2015) Problems of Rural Farmer: A Case Study Based on the Lowphulabori Village under the Raha Block Development Area of Nagaon District, Assam.

[10] Sikha Deka and et al (2017), Socio-Economic Status of Tribal Farmers of Tinsukia District of Assam: A Case Study

[11]Winick, C., 1956. Dictionary of Anthropology, Philosophical Library, New York, P. 546. 